\title{
Haematological and biochemical parameters of blood and immune response of runt weaners
}

\author{
M. Świtała', R. Kolacz ${ }^{2}$, Ewa Bodak-Koszalka² and P. Gajewczyk ${ }^{3}$ \\ 'Department of Pharmacologv and Toxicology \\ 'Department of Animal Hygiene and Livestock Environment \\ ${ }^{3}$ Department of Swine Breeding \\ Agricultural University of Wroclaw \\ Nonvida 31, 50-375 Wroctaw, Poland
}

(Received 25 February 1998; accepted 22 September 1998)

\begin{abstract}
The study was carried out on 45 pigs weaned at 21 days of age with too low body weights, which is referred to as runting-stunting syndrome (RSS). The animals were divided into 3 groups depending on the cause of RSS (low weight at birth, coliform diarrhoea during sucking, or postnatal difficulties in moving). Haematological and biochemical (plasma levels of total protein, bilirubin, blood $\mathrm{Ca}^{-2}$ and $\mathrm{Fe}^{+3}$ contents) parameters were determined in each group on day 7 after weaning. The results were compared with the parameters determined in normal pigs. Some pigs were immunized with sheep erythrocytes (SRBC) on day 10 after weaning. Half the immunized weaners were treated with levamisole $(1 \mathrm{mg} / \mathrm{kg}$ ) for 4 consecutive days to determine the immune response of animals to this immunomodulating agent. Significant changes in biochemical parameters were observed only in pigs with RSS caused by coliform infections. The immune response of pigs with RSS to the immunomodulating dose of levamisole was limited.
\end{abstract}

KEY WORDS: young pigs, runting-stunting syndrome, clinical parameters, immune response, levamisole

\section{INTRODUCTION}

On commercial farms $20-30 \%$ of weaners manifest $10-20 \%$ body weight deficiency (Muirhead, 1990; Balenovic et al., 1994). This disorder is referred to as runting-stunting syndrome (RSS). It may develop both during the prenatal period (runting) or later during sucking (stunting) as a result of unfavourable nutritional environmental - behavioural interactions and/or diseases (Stanton et al., 1974; 
Harstock et al., 1976; , English et al., 1984; Pejsak, 1993; Balenovic et al., 1994). The body weight gain of pigs with RSS never reaches the values noted for normal pigs during fattening.

So far, there have bcen no reports on haematological and biochemical parameters of pigs with RSS, taking into account its causes (low weight at birth, coliform diarrhea during sucking or postnatal difficulties in moving) and the subsequent immune response of the animals.

The aim of the present study was to determine the influence of runting-stunting syndrome on haematological and biochemical blood parameters and the immune response of RSS-weaners to levamisole $(1 \mathrm{mg} / \mathrm{kg})$ immunomodulating treatment.

\section{MATERIAL AND METHODS}

The study was carried out on 45 pigs weaned on 21 day of age. The animals were allocated to four groups. Each group of pigs was kept in a separate pen with free access to water and fed a commercial feed mixture (Prestarter). In group G-I the pigs $(\mathrm{n}=12)$ whose body weight at birth was below $1.1 \mathrm{~kg}$ (runt) were marked and observed during the entire sucking period until weaning. Group G-II consisted of 12 animals selected during the observation period, when RS syndrome developed as a result of colibacteriosis. The pigs in group G-II were collected from litters, where acute diarrhoea occurred and pathogenic strains of $E$. coli had been isolated from dead animals. Group G-III consisted of 12 pigs whose stunting condition was associated with difficulties in moving (parakinesia, congenital muscle hypoplasia, splayleg). The control group G-C consisted of 9 normal pigs randomly selected from the same litters as the affected animals.

Blood samples for haematological and biochemical examinations were collected once, after a 7-day adaptation period. The haematological determinations included: erythrocyte and leukocyte counts, haemoglobin $(\mathrm{Hb})$, haematocrit $(\mathrm{Ht})$, mean cell volume (MCV), mean cell haemoglobin (MCH) and mean cell haemoglobin concentration (MCHC). On the basis of the leukogram the neutrophil index $\mathrm{NI}$ (the ratio of band/segmented neutrophils) was determined. The following biochemical parameters were measured colorimetrically in plasma: the level of bilirubin using sulphanil acid and sodium nitrite $(\mathrm{POCH})$, total protein content using copper sulphate and sodium potassium tartrate (Pointe scientific), iron $\left(\mathrm{Fe}^{-3}\right)$ content using chromazurol $\mathrm{B}$ and cethyltrimethyl ammonium bromide (Analco) and calcium $\left(\mathrm{Ca}^{+2}\right)$ content using o- cresolphtaleine complexone ( Gesellschaft Human Fr Biochemical u. Diagnostica)

When 3 days of observation elapsed (ten days after weaning), 16 piglets were selected at random from groups G-I, G-II and G-III and immunized intraperitoneally with $10 \%$ sheep red blood cells $(\mathrm{SRBC})$ in a dose of $2 \mathrm{ml} / \mathrm{animal}$. Eight 
immunized pigs were treated with levamisole hydrochloride (Biowet, Gorzów, Poland), i.m., in a dose of $1 \mathrm{mg} / \mathrm{kg}$ BW for 4 consecutive days, starting on the day of SRBC immunization. The blood samples were collected prior to immunization and on days 5 and 9 following immunization. The following immunological parameters were tested: (i) the number of neutrophils; (ii) phagocytic activity of neutrophils with nitroblue tetrazolium dye (percentage of NBT-positive cells) according to Park et al. (1968), (iii) the number of lymphocytes; (iv) percentage of T-cells forming E-rosettes according to Binns (1978), using dextran 110; (v) antiSRBC haemagglutinin titers: total and 2-mercaptoethanol resistant (mainly IgG) by active haemagglutination test as described by Adler (1965). The data were analyzed using Statgrafics ver.5. 1 .

\section{RESULTS AND DISCUSSION}

The body weight of normal 21-day-old weaners from group G-C averaged $4.96 \mathrm{~kg}$ (Table 1). On the weaning day the weight deficiency of RSS-pigs, as compared with GC was: $1.87 \mathrm{~kg}(\mathrm{G}-\mathrm{I}) ; 1.40 \mathrm{~kg}$ (G-II), and $0.93 \mathrm{~kg}$ (G-III), respectively $(\mathrm{P}<0.01)$. The body weight gain of RSS-pigs (mean of G-I, G-II and G-III) was $36.7 \%$ lower than that of normal pigs in group G-C. Average daily gain (ADG) in G-I and G-II was nearly the same, but $17.6 \%$ lower than that in G-III.

TABLE 1

Body weight $(\mathrm{kg})$ and average daily gain $(\mathrm{g})$ in weaners

\begin{tabular}{|c|c|c|c|c|c|}
\hline & & $\begin{array}{l}\text { Normal pigs } \\
\text { (control) }\end{array}$ & \multicolumn{3}{|c|}{ Pigs with runting-stunting syndrome } \\
\hline & & $\begin{array}{l}\text { (control) } \\
\text { G-C } \\
n=9\end{array}$ & $\begin{array}{c}\text { low birth } \\
\text { weight } \\
\mathrm{G}-\mathrm{I} \\
\mathrm{n}=12\end{array}$ & $\begin{array}{c}\text { coliform } \\
\text { diarrhoea } \\
\text { G-II } \\
n=12\end{array}$ & $\begin{array}{c}\text { motorial } \\
\text { disordes } \\
\mathrm{G}-\mathrm{III} \\
\mathrm{n}=12\end{array}$ \\
\hline $\begin{array}{l}\text { Body weight } \\
\text { at birth }\end{array}$ & $\begin{array}{c}\mathrm{M} \\
+\mathrm{SD}\end{array}$ & $\begin{array}{r}1.39 \\
\pm 0.50\end{array}$ & $\begin{array}{r}1.01 \\
\pm 0.63\end{array}$ & $\begin{array}{r}1.41 \\
\pm 0.28\end{array}$ & $\begin{array}{r}1.46 \\
\pm 0.43\end{array}$ \\
\hline $\begin{array}{l}\text { Body weight } \\
\text { at weaning }\end{array}$ & $\begin{array}{c}\mathrm{M} \\
+\mathrm{SD}\end{array}$ & $\begin{array}{r}4.96 \\
\pm 0.61\end{array}$ & $\begin{aligned} & 3.09^{*} \\
\pm & 0.49\end{aligned}$ & $\begin{array}{r}3.56 \\
\pm 1.23\end{array}$ & $\begin{array}{r}4.03 \\
\pm 0.79\end{array}$ \\
\hline Average daily gain & & 127 & 74 & 76 & 91 \\
\hline
\end{tabular}

$* \mathrm{P}<0.05$ ( $\mathrm{t}$-test)

Pigs runt at birth (prenatal runting) are not able to reach normal body weight long after birth (Balenovic et al., 1994), but if they are separated from the litter and fed artificially, they grow faster and are able to achieve a body weight gain comparable to unaffected pigs (England, 1986; Muirhead, 1990). The results presented in this study show that infectious diseases of piglets with normal weight at birth 
TABLE 2

Haematological and biochemical parameters in weaners

\begin{tabular}{|c|c|c|c|c|c|}
\hline & & \multirow{2}{*}{$\begin{array}{l}\text { Normal pigs } \\
\text { (control) } \\
\text { G-C } \\
n=9\end{array}$} & \multicolumn{3}{|c|}{ Pigs with runting-stunting syndrome } \\
\hline & & & $\begin{array}{c}\text { low birth } \\
\text { weight } \\
\text { G-I } \\
n=12\end{array}$ & $\begin{array}{c}\text { coliform } \\
\text { diarrhoea } \\
\text { G-Il } \\
n=12\end{array}$ & $\begin{array}{c}\text { motorial } \\
\text { disordes } \\
\mathrm{G}-\mathrm{III} \\
\mathrm{n}=12\end{array}$ \\
\hline Erythrocytes, T/I & $\begin{array}{c}\mathrm{M} \\
\pm \mathrm{SD}\end{array}$ & $\begin{array}{l}5.35 \\
0.50\end{array}$ & $\begin{array}{l}5.61 \\
0.45\end{array}$ & $\begin{array}{l}5.43 \\
0.51\end{array}$ & $\begin{array}{l}5.30 \\
0.59\end{array}$ \\
\hline $\mathrm{Hb}, \mathrm{mM} / 1$ & $\begin{array}{c}\mathrm{M} \\
\pm \mathrm{SD}\end{array}$ & $\begin{array}{l}8.32 \\
0.57\end{array}$ & $\begin{array}{l}8.42 \\
0.87\end{array}$ & $\begin{array}{l}8.03 \\
0.62\end{array}$ & $\begin{array}{l}7.83 \\
1.11\end{array}$ \\
\hline $\mathrm{Ht}, \mathrm{L} / \mathrm{L}$ & $\begin{array}{c}\mathrm{M} \\
\pm \mathrm{SD}\end{array}$ & $\begin{array}{l}0.42 \\
0.03\end{array}$ & $\begin{array}{l}0.43 \\
0.03\end{array}$ & $\begin{array}{l}0.40 \\
0.04\end{array}$ & $\begin{array}{l}0.39 \\
0.06\end{array}$ \\
\hline $\mathrm{CV}, \mathrm{fl}$ & $\begin{array}{c}\mathrm{M} \\
\pm \mathrm{SD}\end{array}$ & $\begin{array}{r}78.5 \\
7.3\end{array}$ & $\begin{array}{r}76.6 \\
9.1\end{array}$ & $\begin{array}{r}73.6 \\
8.6\end{array}$ & $\begin{array}{l}73.6 \\
10.2\end{array}$ \\
\hline $\mathrm{MCH}, \mathrm{fmol}$ & $\begin{array}{c}\mathrm{M} \\
\pm \mathrm{SD}\end{array}$ & $\begin{array}{l}1.55 \\
0.14\end{array}$ & $\begin{array}{l}1.50 \\
0.13\end{array}$ & $\begin{array}{l}1.47 \\
0.27\end{array}$ & $\begin{array}{l}1.47 \\
0.17\end{array}$ \\
\hline $\mathrm{MCH}, \mathrm{mmol} / \mathrm{L}$ & $\begin{array}{c}\mathrm{M} \\
\pm \mathrm{SD}\end{array}$ & $\begin{array}{r}19.8 \\
2.8\end{array}$ & $\begin{array}{r}19.6 \\
2.1\end{array}$ & $\begin{array}{r}20.7 \\
4.2\end{array}$ & $\begin{array}{r}20.1 \\
3.1\end{array}$ \\
\hline Leukocytes, G/L & $\begin{array}{c}\mathrm{M} \\
\pm \mathrm{SD}\end{array}$ & $\begin{array}{l}22.9 \\
11.9\end{array}$ & $\begin{array}{l}22.6 \\
10.2\end{array}$ & $\begin{array}{l}23.8 \\
12.5\end{array}$ & $\begin{array}{r}22.4 \\
8.4\end{array}$ \\
\hline Total bilirubin, $\mathrm{uM} / \mathrm{L}$ & $\begin{array}{c}\mathrm{M} \\
\pm \mathrm{SD}\end{array}$ & $\begin{array}{l}3.91 \\
1.44\end{array}$ & $\begin{array}{l}3.47 \\
1.96\end{array}$ & $\begin{array}{l}2.93^{*} \\
1.34\end{array}$ & $\begin{array}{l}3.18 \\
0.90\end{array}$ \\
\hline Total protein, $\mathrm{g} / \mathrm{L}$ & $\begin{array}{c}\mathrm{M} \\
\pm \mathrm{SD}\end{array}$ & $\begin{array}{r}66.88 \\
4.62\end{array}$ & $\begin{array}{r}64.09 \\
8.33\end{array}$ & $\begin{array}{c}60.51^{*} \\
3.62\end{array}$ & $\begin{array}{r}66.51 \\
8.29\end{array}$ \\
\hline $\mathrm{Fe}, \mathrm{umol} / \mathrm{L}$ & $\begin{array}{c}\mathrm{M} \\
\pm \mathrm{SD}\end{array}$ & $\begin{array}{r}18.61 \\
6.90\end{array}$ & $\begin{array}{r}23.25 \\
6.17\end{array}$ & $\begin{array}{r}22.54 \\
6.28\end{array}$ & $\begin{array}{r}19.03 \\
3.06\end{array}$ \\
\hline $\mathrm{Ca}, \mathrm{mM} / \mathrm{L}$ & $\begin{array}{c}\mathrm{M} \\
\pm \mathrm{SD}\end{array}$ & $\begin{array}{l}2.74 \\
0.22\end{array}$ & $\begin{array}{l}2.60 \\
0.26\end{array}$ & $\begin{array}{l}2.55^{*} \\
0.09\end{array}$ & $\begin{array}{l}2.45^{*} \\
0.21\end{array}$ \\
\hline
\end{tabular}

$* \mathrm{P}<0.05(\mathrm{t}$-test $)$

(G-II) affect body weight gain to a similar degree as runting syndrome (G-I) whereas . noninfectious diseases (G-III) make the syndrome of stunting less pronounced.

The haematological parameters in pigs from G-I, G-II and G-III were not significantly different, and they did not differ from the control group, either (Table 2), hence, the mean values did not exceed the physiological standards (Friendship et al., 1984; Kłopocki et al., 1987; Vigo et al., 1992) examined haematological indices 
in runt pigs and compared the results with the respective values of normal pigs. They found slight differences between those groups in crythrocyte, leukocyte, $\mathrm{Hb}$ and $\mathrm{Ht}$ contents. No differences in $\mathrm{MCV}, \mathrm{MCH}$ and $\mathrm{MCHC}$ were observed.

In group G-II, the total protein content was $10.8 \%$ lower $(\mathrm{P}<0.05)$, bilirubin content was $25.1 \%$ lower $(\mathrm{P}<0.05)$ and $\mathrm{Ca}^{+2}$ content was $8.0 \%$ lower $(\mathrm{P}<0.05)$, as compared with G-C. The $\mathrm{Ca}^{-2}$ content in group G-III was $10.6 \%$ lower $(\mathrm{P}<0.05)$ than that of the control group (G-C). No differences in the indices measured were found between G-I and G-C (Table 2). Correlation coefficients for the entire RSS population were as follows: body weight $x$ total protein, $r=0.40(\mathrm{P}<0.02)$; body weight $\times \mathrm{Ca}^{+2}, \mathrm{r}=0.45(\mathrm{P}<0.01)$ and body weight $\times \mathrm{Fe}^{+3}, \mathrm{r}=-0.37(\mathrm{P}<0.04)$.

TABLE 3

Blood leucocytes (\%) in weaners

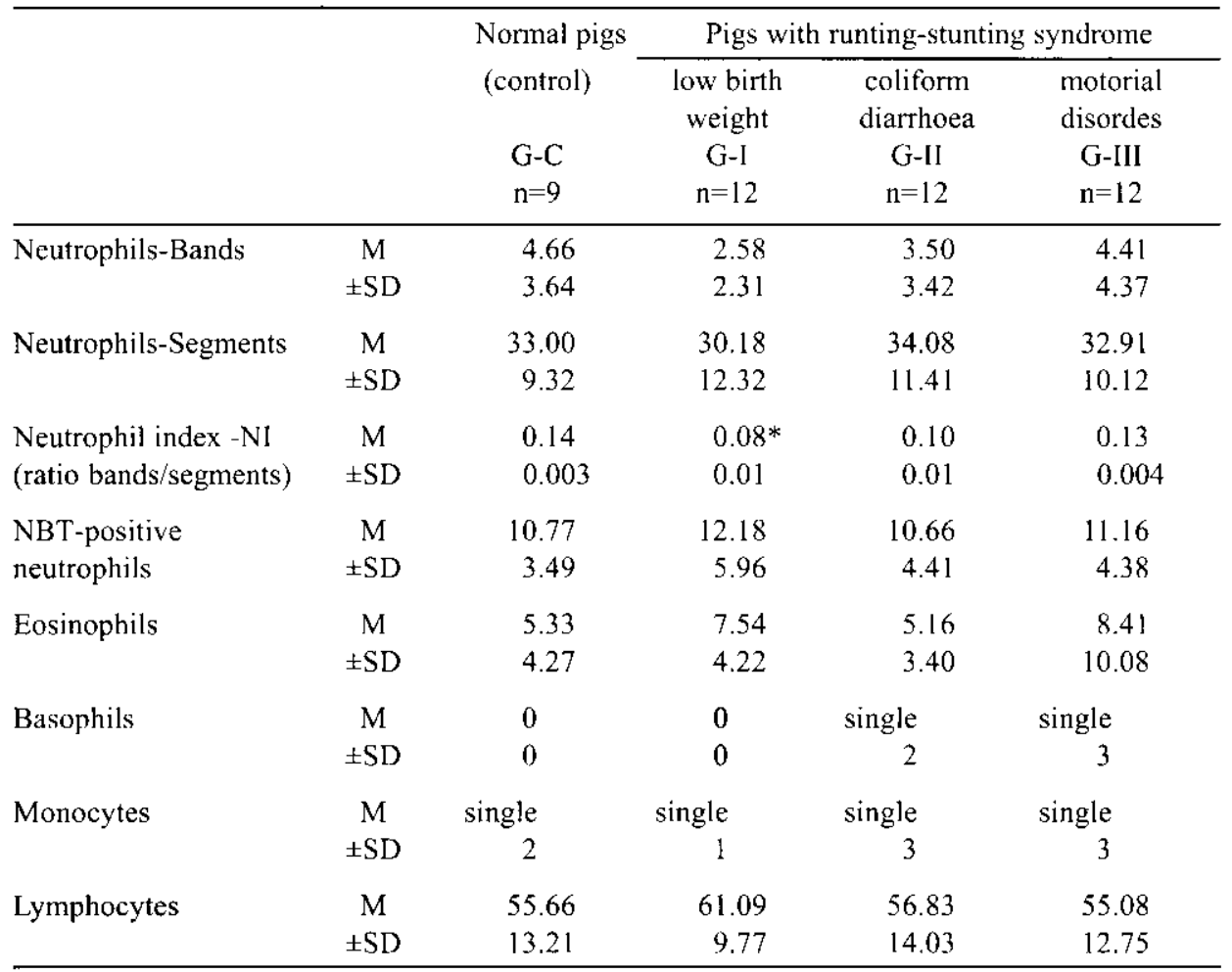

* $\mathrm{P}<0.05(\mathrm{t}$-test $)$

The differences in neutrophil index (NI) were found between the groups (Table 3). In group $\mathrm{G}-\mathrm{C}$ the $\mathrm{NI}$ was the highest $(0.141)$ and comparable to that in group GIII $(0.134)$, while the lowest value was noted in G-I pigs (0.08). Bartnicka and Kondracki (1984) claim that the shift of the white cell picture toward immature 


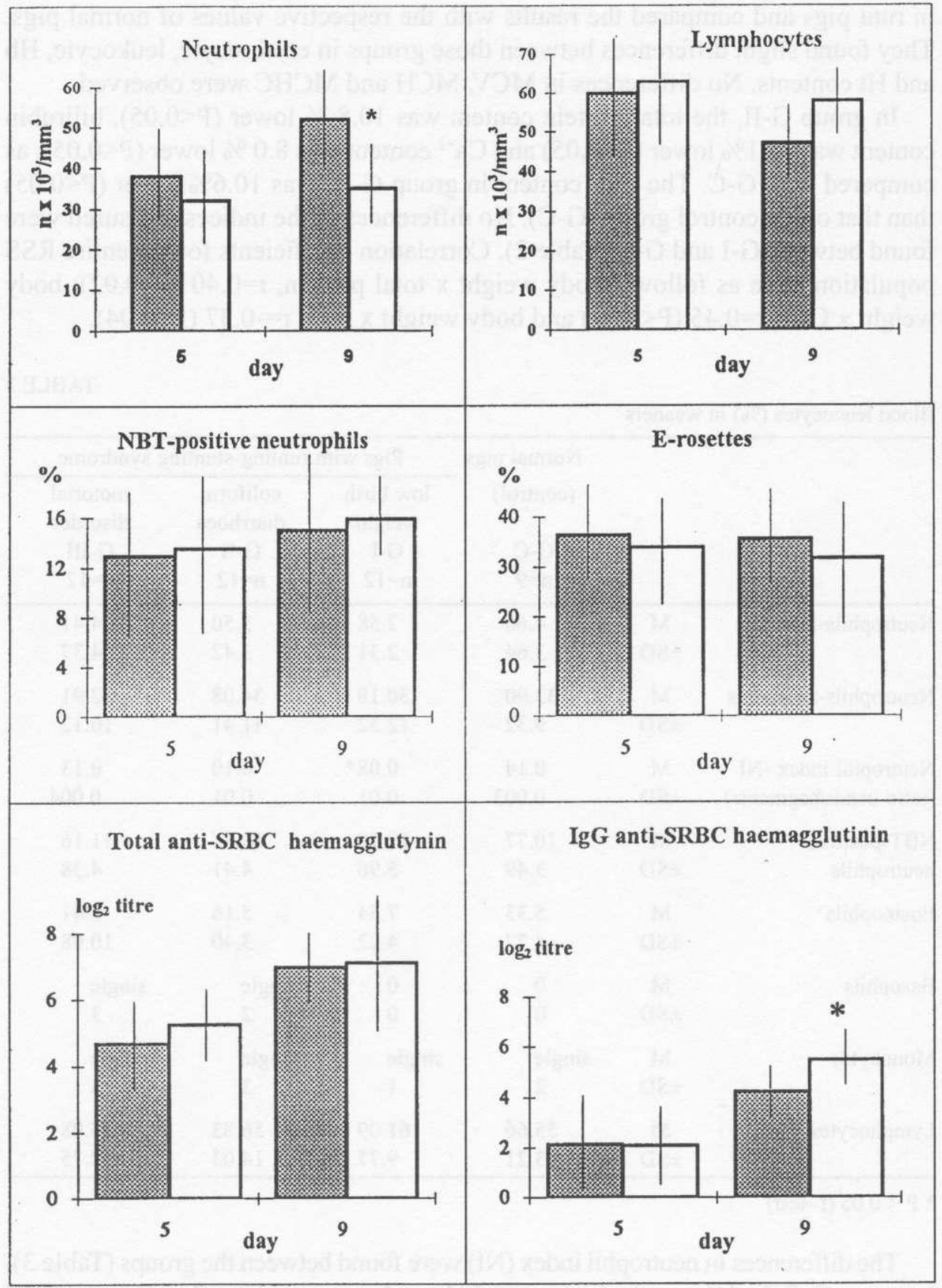

खontrol

Dlevamisole

Figure 1. Immunological indices in runt pigs immunized with SRBC 
forms may indicate higher granulopocsis ability or higher concentration of young neutrophils in the bone marrow. As far as the remaining values of the leukogram are concerned, no significant differences between the groups were found. The eosinophil populations in G-III and G-I were 36.3 and $29.3 \%$ higher than in group $\mathrm{G}-\mathrm{C}$, respectively.

The most significant differences in haematological and biochemical parameters (Table 2) were found in the pigs which had been infected with colibacteriosis (G-II). Coliform diarrhoca lcads to malabsorption and dehydration which in turn impair homeostasis (Depta, 1984; Wójcik, 1985). G-II pigs show that infectious diseases during the sucking period not only inhibit body weight gain, but also affect biochemical indices after weaning. In group G-II the correlation coefficient between $\mathrm{Fe}^{\cdot 3}$ content and the number of NBT-positive cells was significant $(r=-0.71 ; P<0.01)$. This may suggest enhanced neutrophil activity in the pigs low in serum $\mathrm{Fe}^{+3}$ due to infectious discases. Gherke (1989) reports that reduced $\mathrm{Fe}^{-3}$ concentration in blood does not allow the microorganisms to restore $\mathrm{Fe}^{+3}$ to levels sufficient for enzymatic processes in cells.

G-III pigs (having difficulties in moving) were exposed to chronic stress with limited access to feed, resulting in malnutrition and emotional disorders due to lower rank in the litter hierarchy. Fitko et al. (1988) indicate that this somaticemotional stress affects haematological and biochemical parameters to a lesser degree than acute stress (shift to different nursery groups, transportation).

Figure 1 shows immunological indices of SRBC-immunized RSS-pigs. There was a decrease in the number of lymphocytes $(20 \%)$ and the increase $(\mathrm{P}<0.05)$ in neutrophils $(40 \%)$ on day 9 following SRBC immunization. On day 5 following SRBC immunization, anti-SRBC haemagglutinin titer (IgG class) accounted for $50 \%$ of total SRBC haemagglutinin titer and reached $60 \%$ on day 9 after immunization. The effects of levamisole on phagocytic activity of neutrophils (NBT), the percentage of T-lymphocytes forming E-rosettes and total anti-SRBC haemagglutinin titers in serum were insignificant, but levamisole significantly increased the class IgG titer of anti-SRBC haemagglutinins, which on day 9 accounted for $80 \%$ of specific haemagglutinins.

Levamisole is an immunomodulating agent commonly used in veterinary practice $(0.5-2.0 \mathrm{mg} / \mathrm{kg})$. It is well-known for its ability to restore T-lymphocytes and humoral response to T-dependent antigen, such as SRBC, and stimulate neutrophil activity. The mechanism of levamisole activity is well known (Renoux, 1985; Świtała, 1992), therefore it is used in research as a reference agent. The enhanced production of $\operatorname{lgG}$ specific antibodies coinciding with the primary humoral response to T-dependent antigen is connected with the stimulation of T-lymphocyte activity, which is a typical effect of levamisole.

Our results indicate that levamisole action in RSS-pigs was seriously limited, as it did not affect the activity of neutrophils and percentage of T-lymphocytes 
forming E-rosettes. However, levamisole administered to older RSS-weaners increased the indices significantly (Świtała, 1992; Kołacz et al., 1994). Hennesy et al. (1987) report that levamisole affects cellular immune response of piglets during the first four weeks of age.

\section{CONCLUSIONS}

The stunted growth of young pigs suffering from coliform infections during the sucking period corresponded with significant changes in biochemical parameters of blood. In pigs showing difficulties in moving, the stunting syndrome was less advanced than in the other groups. No changes in haematological and biochemical parameters of pigs with low body weight at birth were found, however, the runts were not able to reach the body weight of normal pigs. The effect of levamisole injected in a low, immunomodulating dose $(1 \mathrm{mg} / \mathrm{kg})$ to runts weaned 21 days after birth and SRBC-immunized on day 10 after weaning, was limited.

\section{REFERENCES}

Adler F.L., 1965. Studies on mouse antibodies. J. Immunol. 95, 26-46

Balenovic T., Vrbanac I., Susic V., Vijtiuk N., Krsnik B., 1994. Age-related growth of weaned pigs: correlation between live body weight gain at the start and finish of rearing period. Proceedings of 13th IPVS Congress, Bangkok (Thailand), p. 138

Bartnicka B., Kondracki M., 1984. The influence of immunostimulators on certain mechanisms of cellular immunity in newborn piglets (in Polish). Med. wet. 40, 693-695

Binns R.M., 1978. Sheep erythrocytes rosettes in pigs, cattle and goats demonstrated in the presence of dextran. J. Immunol. Meth. 21, 197-210

Depta A., 1984. Disturbances of water-electrolite balance and acid-base balance in dehydrated piglets. Zesz. nauk. ART 0lsztyn, Wet. 15, 43-86

England D.C., 1986. Improving sow efficiency by management to enhance opportunity for nutritional intake by neonatal piglets. J.Anim. Sci. 63, 1297-1306

English P.R., Morrison V., 1984. Causes and prevention of piglet mortality. Pig News Inf. 5, 369-376

Fitko R., Kowalski A., Zieliński H., 1988. The level of catecholamines and cortisol in blood of animals under various stress conditions caused by a technology of industrialized farming (in Polish). Med. wet. 44, 416-418

Friendship R.M., Lumsden J.H., McMillian I., Wilson M.R., 1984. Hematology and biochemistry reference values for Ontario swine. Can. J. Comp. Med. 48, 390-394

Gherke M.,1989 The role of proteins conjugating iron in immunity of the alimentary tract (in Polish). Med. wet. $45,100-103$

Harstock T.G., Graves H.B., 1976. Neonatal behavior and nutrition related mortality in domestic swine. J. Anim. Sci. 42, 235-241

Hennessy K.J., Blecha F., Pollmann D.S., Kluber E.F., 1987. Isoprinosine and levamisole immunomodulation in artificially reared neonatal pigs. Amer. J. Vet. Res. 48, 477-480 
Kłopocki T., Winnicka A., 1987. Normal Values in Basic Labolatory Parameters for Veterinary Practice (in Polish). Warsaw Agricultural University Press

Kołacz R., Świtała M., Bodak-Koszałka E., Obmińska-Domoradzka B., Dębowy J., 1994. Levamisole and mechloretamine in immunostimulating doses and herbs as immunorestorative agents for weaned pigs with runting syndrome. Proceedings of VIII International Congress of Animal Hygiene. St. Paul, Minnesota (USA), pp. $105-110$

Muirhead S.,1990. Determination of potential growth runt piglets. Feedstuffs $62(36), 10$

Park B.H., Firkig S., Smithwick E.M., 1968. Infection and nitroblue tetrazolium reduction by neutrophils. Lancet 2, 532-534

Pejsak Z., 1993. Limited of weigh gain and feed utilization due to young pig diseases (I) (in Polish). Trzoda chl. 31 (3), 15-16

Renoux G., 1985. Modulation of immunity by levamisole and DTC. In: M. S. Mitchell (Editor). The modulation of immunity. Pergamon Press, Oxford, New York, Toronto, Sydney, Frankfurt, pp. 393

Stanton H.C, Carroll J.K., 1974. Potential mechanism responsible for prenatal and perinatal mortality and low viability. J.Anim. Sci. 38, 1038-1044

Switała M., 1992. Comparison of immunostimulating properties of low dose mechlorethamine with levamisole in experimental and clinical studies (in Polish). Zesz. nauk. AR Wroctaw, Ser. Thesis, No. 104 , pp. $1-84$

Vigo D., Nisoli L.G.C., Colombani C., Foccoli E., Sala V., Maffeo G., 1992. Hematological values in pigs with growth retardation syndrome. Sel .Vet. 33, 927-930

Wójcik J.,1985. Epidemic swine diarrrhoe (in Polish). Med wet. 41, 711-715

\section{STRESZCZENIE}

\section{Wskaźniki hematologiczne i biochemiczne krwi oraz odpowiedź immunologiczna odsadzonych świń z syndromem charłactwa}

Badania przeprowadzono na 45 prosiętach, odłączonych od matek w 21 dniu życia, z niedoborem masy ciała określanym jako runting-stunting syndrom (RSS). Zwierzęta podzielono na 3 grupy w zależności od przyczyny RSS (niska masa po urodzeniu, przebyte w okresie ssania biegunki na tle zakażeń $E$. coli lub nabyte uszkodzenia aparatu ruchu). Siedem dni po odsadzeniu u wszystkich prosiąt oznaczono we krwi poziom białka całkowitego, bilirubiny oraz jonów wapnia i żelaza. Wyniki porównano z wartościami określonymi u normalnie rozwiniętych świń. W 10 dniu po odsadzeniu część prosiąt poddano immumizacji krwinkami owcy. Połowie immunizowanych zwierząt podawano lewamizol w dawce $\mathrm{l} \mathrm{mg} / \mathrm{kg}$ przez 4 kolejne dni, w celu określenia odpowiedzi immunologicznej zwierząt na ten immunomodulujący środek. Statystycznic istotne zmiany wskaźników biochemicznych krwi stwierdzono tylko u prosiąt $z$ RSS po przebytych biegunkach na tle zakażeń E. coli. Odpowiedź immunologiczna świń z RSS na immunostymulującą dawkę lewamizolu była ograniczona. 